\title{
ANALISIS LAPORAN KEUANGAN SEBAGAI BAHAN PERTIMBANGANPEMBERIAN KREDIT (Studi Pada Lembaga Keuangan Di Kota Malang)
}

\author{
Nanik Wahyuni \\ Fakultas Ekonomi,Universitas Islam Negeri Maulana Malik Ibrahim Malang \\ Jl. Gajayana 50 Malang Telp. 0341-551354 Faks. 0341-572533 \\ e-mail : /HP : 081233381656
}

\section{ABSTRACT}

This research aims to determine the the basis of valuation and credit analysis in the loan application process on the existing financial institutions in the city of Malang. In addition, provide the evidence that the financial statements have a very important role in the mortgage application process on the existing financial institutions in the city of Malang. The research used a quantitative research study in financial management that analyzed the financial statements of the debtor with the status of legal entities that are used in the provision of credit to financial institutions in the city of Malang. Data analysis techniques use ratio analysis, comparative analysis of financial statements, common size analysis.

Keyword : Credit, Financial Institutions, Financial Statements

\section{PENDAHULUAN}

Lembaga keuangan memainkan peranan penting dalam perekonomian. Lembaga keuangan bertindak sebagai perantara antara unit yang surplus dengan unit yang defisit. Lembaga Keuangan juga berfungsi untuk meningkatkan efisiensi alokasi sumber daya dalam ekonomi modern (Sinkey, 2002;. El-Hawary et al, 2007). Liberalisasi keuangan dan revolusi teknologi juga telah meningkatkan tekanan kompetitif di antara lembaga keuangan. Lembaga-lembaga keuangan diberi fleksibilitas untuk mengembangkan strategi mereka sendiri agar tetap kompetitif. Kemajuan dalam teknologi telah memungkinkan mereka untuk mengembangkan cara baru dan pengolah an saluran yang lebih efisien, serta menciptakan produk dan model pelayanan baru yang lebih inovatif.

Kemampuan manajemen dalam membuat keputusan terkait dengan kualitas informasi manajemen yang ada (Kafafian, 2001; Rezaee, 2005) dan informasi yang baik muncul dari sistem akuntansi manajemen yang efektif (MAS) sebagai alat penting dalam memberikan informasi dalam pengambilan keputusan (Cole, 1988).

Kredit perbankan bagaimanapun juga tetap mengandung resiko. Resiko terbesar yang mungkin dapat terjadi adalah timbulnya kredit macet. Yaitu kredit yang diberikan tidak hanya mengalami keterlambatan dalam pelunasannya tapi bahkan mungkin tidak dapat ditagih atau akan macet sama sekali pembayarannya. Untuk 
menarik kembali kredit macet dari debitur, dibutuhkan keahlian, pengalaman, serta waktu dan biaya yang cukup besar, kredit macet dalam jumlah yang besar dapat mengganggu perekonomian, serta menurunkan kepercayaan masyarakat dalam dan luar negeri terhadap profesionalisme pengelolaan perbankan nasional. Kredit macet terjadi bukan hanya disebabkan oleh debitur, namun dapat juga terjadi karena pihak lembaga keuangan selaku pemberi kredit terlalu mudah dalam memberikan kreditnya. Lembaga keuangan perlu mengetahui terlebih dahulu posisi keuangan dari perusahaan yang memohon kredit (debitur) yaitu melalui penganalisaan laporan keuangan. Laporan keuangan merupakan alat yang sangat penting untuk memperoleh informasi sehubungan dengan posisi keuangan dan hasil-hasil yang telah dicapai oleh perusahaan yang bersangkutan selama periode tertentu. Di dalam mengambil keputusan untuk menerima atau menolak permohonan kredit yang diajukan oleh debitur, maka lembaga keuangan selain mempertimbangkan aspek-aspek secara teknis yang lebih dikenal dengan istilah $5-\mathrm{C}$ juga mempertimbangkan hasil analisis laporan keuangan perusahaan debitur.

Sesuai uraian diatas dan dengan melihat betapa pentingnya pemberian kredit bagi perusahaan, maka rumusan dalam penelitian ini adalah, "Bagaimana penerapan analisis laporan keuangan digunakan untuk menilai kelayakan calon debitur dalam pemberian kredit pada lembaga keuangan yang ada di kota Malang"

Penelitian ini bertujuan untuk mengetahui dasar penilaian dan analisis kredit dalam proses permohonan kredit pada lembaga keuangan yang ada di kota Malang. Selain itu juga untuk memberikan bukti bahwa laporan keuangan mempunyai peranan yang sangat penting dalam proses permohonan kredit pada lembaga keuangan yang ada di kota Malang.

\section{Laporan Keuangan}

Industri baik manufaktur dagang maupun jasa perlu adanya suatu administrasi untuk mencatat dan melaporkan semua kegiatan dengan baik dan akurat sebagai sebuah informasi kuantitatif yang bersifat moneter. Kegiatan akuntansi pada dasarnya merupakan mencatat, menganalisa, menyajikan dan menafsirkan data keuangan dari suatu perusahaan atau badan usaha lainnya. Kegiatan akuntansi inilah yang menghasilkan laporan keuangan. Laporan keuangan merupakan hasil akhir dari proses akuntansi yang meliputi: (1) Neraca, (2) Perhitungan laba rugi dan laba ditahan, (3) Laporan perubahan posisi keuangan serta, (4) Catatan atas laporan keuangan. Laporan keuangan disusun dengan maksud untuk menyediakan informasi mengenai 
suatu perubahan kepada pihak yang berkepentingan di dalam pengambilan keputusan Menurut. (Baridwan,zaki (2000:17). Laporan keuangan adalah neraca dan perhitungan laba-rugi serta segala keterangan yang dimuat dalam lampiran-lampirannya antara lain laporan sumber dan penggunaan dana. (Bambang.S (2005:3). Adapun tujuan laporan keuangan adalah menyediakan informasi keuangan dari suatu badan usaha dari pihakpihak yang berkepentingan yaitu pemilik perusahaan, manajer, investor, kreditor, dan pemerintah

\section{Teknik Analisis Laporan Keuangan}

Teknik analisis yang digunakan dalam analisis laporan keuangan, menurut Munawir (2002: 36) adalah :

a. Analisa Ratio, merupakan teknik analisis yang mengetahui hubungan dan pos-pos tertentu dalam neraca dan lapóran-laba secara individu atau kombinasi keduanya. Analisis ratio dapat digolongkan dalam beberapa golongan, yaitu:

1) Rasio likuiditas, yaitu untuk mengukur kemampuan suatu perusahaan dalam memenuhi kewajiban jangka pendeknya. Rasio ini dapat meliputi rasio yang mengukur efisiensi penggunaan aktiva lancar, yang meliputi

a. Current ratio $=\frac{\text { aktiva lancar }}{\text { Hutang lancar }} \times 100 \%$

b. Quick ratio $=\frac{\text { aktiva lancar }- \text { Persediaan }}{\text { Hutang lancar }} \times 100 \%$

c. Cash $=\frac{\text { kastefek }}{\text { hutanglancar }} \times 100 \%$

2) Rasio Solvabilitas

Yaitu suatu rasio yang digunakan untuk mengukur sejauh mana perusahaan yang dibiayain dengan hutang. Rasio solvabilitas yaitu:

1) Total asset ratio $=\frac{\text { Total Utang }}{\text { Total Aktiva }} \times 100 \%$

2) Total debt to equity ratio $=\frac{\text { Total Hutang }}{\text { Modal sendiri }} \times 100 \%$

3) Long term debt equity ratio $=\frac{\text { utang jangka panjang }}{\text { Modal sendiri }} \times 100 \%$

4) Time interest earned ratio $=\frac{\mathrm{EBIT}}{\text { Beban bunga }} \times 100 \%$

3) Rasio Aktivitas 
Yaitu rasio yang mengukur seberapa efektif perusahaan dalam menggunakan sumber danannya. Rasio aktifitas antara lain :

1) Total asset turn over $=\frac{\text { Penjualan }}{\text { Total aktiva }}$

2) Receivable turn over $=\frac{\text { Penjualan Bersih }}{\text { Piutang rata }- \text { rata }}$

3) Average collection period $=\frac{360}{\text { Receivable turn over }} \times 1$ Hari

4) Working capital trun over $=\frac{\text { penjualan bersih }}{\text { Aktiva lancar }- \text { utang lancar }} \times 1$ Hari

5) Average Day's inventory $=\frac{360}{\text { inventory trun over }} \times 1$ Hari

6) Inventory trun over $=\frac{360}{\text { inventory turn over }} \times 1$ Hari

4) Rasio Profitabilitas

Yaitu rasio yang digunakan untuk mengukur kemampuan perusahaan dalam menghasilkan laba. antara lain :

1) Grossprofit margin $=\frac{\text { penjualan }- \text { harga pokok penjualan }}{\text { Penjualan }} x 100 \%$

2) Operating income ratio $=\frac{\text { laba usaha }}{\text { Penjualn }} \times 100 \%$

3) Operating ratio $=\frac{\text { Harga pokok penjualan }+ \text { Biaya operasi }}{\text { penjualan }} \times 100 \%$

4) Return on equity $=\frac{\text { Laba bersih setelah pajak }}{\text { jumlah aktiva }} \times 100 \%$

5) Rentabilitas modal sendiri $=\frac{\text { laba bersih setelah pajak }}{\text { modal sen diri }} \times 100 \%$

6) Net Profit Margin $=\frac{\text { Laba Bersih Setelah Pajak }}{\text { Penjualan }} \times 100 \%$

b. Analisis komparatif (Perbandingan Laporan Keuangan)

Analisis ini dilakukan dengan cara membandingkan laporan keuangan dua periode atau lebih. Dari perbandingan tersebut akan diketahui perkembangan pos-pos yang ada pada laporan keuangan (minimal meliputi aktiva, hutang modal, pendapatan, biaya, laba-rugi dari satu periode dengan periode lainnya), dengan menunjukan:

1) Data absolut atau jumlah-jumlah dalam rupiah. 
2) Kenaikan atau penurunan dalam jumlah rupiah.

3) Kenaikan atau penurunan dalam porsentase.

4) Perbandingan yang dinyatakan dengan rasio.

5) Persentase dari total.

Analisa dengan metode ini akan dapat menjadi perubahan-perubahan yang terjadi.

c. Trend Percentage analysis

Adalah suatu metode dan teknis analisis untuk mengetahui tendensi dan keadaan keuangan, apakah menunjukkan tendensi yang tetap, naik atau turun.

d. Analisis Prosentase Per Komponen (Common Size Percentage)

Analisa ini digunakan untuk mengamati prosentase investasi pada masingmasing aktiva terhadap total aktivanya, juga dapat diketahui permodalan dan komposisi beban yang terjadi dihubungkan dengan jumlah penjualannya. Dengan prosentase tiap komponen dengan perhitungan, prosentaseprosentase tersebut adalah sebagai berikut :
a) $=\frac{\text { saldo pihutang }}{\text { total aktiva }} \times 100 \%$
b) $=\frac{\text { Saldo hutang dagang }}{\text { total pasiva }} \times 100 \%$
c) $=\frac{\text { Harga pokok penjualan }}{\text { penjualan netto }} \times 100 \%$
d) $=\frac{\text { Laba operasiaon al }}{\text { penjualan netto }} \times 100 \%$

e. Analisa Sumber dan Penggunaan Modal Kerja ada tiga konsep yang digunakan yaitu:

a) Konsep kuantitatif

Dalam konsep ini yang dianggap sebagai modal kerja adalah jumlah aktiva lancar.

b) Konsep kualitatif

Menekankan pada kualitas modal kerja, bahwa modal kerja yaitu kelebihan (sisa) antara aktiva lancar dengan hutang lancar.

c) Konsep fungsional

Ditekankan pada fungsi dan dana yang dimiliki perusahaan dalam usaha menghasilkan keuntungan (laba) dan usaha perusahaan sehari -hari.

f. Analisa sumber dan penggunaan Kas 
Analisis ini digunakan untuk mengetahui sebab-sebab perubahan jumlah uang kas atau untuk mengetahui sumber-sumber serta penggunaan uang kas selama periode tertentu.

g. Analisis perubahan laba kotor

Analisis yang digunakan untuk mengetahui sebab perubahaan laba kotor suatu perusahaan dari sumber periode ke periode yang lain atau perubahan laba kotor suatu periode dengan laba yang digunakan untuk periode tersebut.

h. Analisis break even

Analisis ini digunakan untuk menentukan tingkat penjualan yang harus dicapai oleh suatu perusahaan agar perusahaan tersebut tidak rugi, tetapi juga belum memperoleh keuntungan.

\section{Kredit}

Kredit berasal dari bahasa latin (credere) yang berarti percaya. Karena itu kredit menyangkut kepercayaan yang timbul sebagai interaksi antara dua pihak yaitu pihak pemberi kredit (bank) dan pihak penerima kredit (debitur), yang dikaitkan dengan kegiatan usaha yang memiliki nilai ekonomi, dikembalikan dengan jangka waktu tertentu dan bunga yang ditetapkan.Sedangkan menurut Undang-Undang Perbankan No. 10 Tahun 1998 pasal 1 tentang Perbankan adalah: Kredit adalah penyediaan uang atau tagihan yang dapat dipersamakan dengan itu, berdasarkan persetujuan atau kesepakatan pinjam-meminjam antara bank dengan pihak lain yang mewajibkan pihak peminjam untuk melunasi utangnya setelah jangka waktu tertentu dengan pemberian bunga, imbalan atau pembagian keuntungan. Menurut Malayu Hasibuan (2001:41), kredit adalah semua jenis pinjaman yang harus dibayar kembali bersama bunganya oleh peminjam sesuai dengan penjanjian yang telah disepakati.

\section{Prinsip Penilaian Kredit}

Berikut prinsip penilaian kredit yang sehat (kualitatif) yang berlaku, sebagai bahan pertimbangan pemberian kredit menggunakan prinsip 5C.Manurung, (2004:193194). adalah:

a. Character

Suatu keyakinan bahwa sifat atau watak seorang calon debitur benar-benar dapat dipercaya, hal ini tercermin dari latar belakang calon debitur yang bersifat pribadi seperti : gaya hidup, keadaan keluarga, hobi serta perilaku calon debitur. Ini semua merupakan ukuran "kemauan" membayar kredit yang diterimanya. 


\section{b. Capacity}

Untuk melihat nasabah dalam kemampuannya dibidang bisnis yang dihubungkan dengan pendidikannya, kemampuan bisnis juga diukur dengan kemampuannya dalam memahami ketentuan-ketentuan pemerintah. Begitu pula dengan kemampuannya dalam menjalankan usahanya selama ini. Pada akhirnya akan terlihat "kemampuan" calon debitur dalam mengembalikan kredit yang disalurkan.

c. Capital

Untuk melihat penggunaan modal apakah efektif, dapat dilihat dari laporan keuangan dengan melakukan pengukuran seperti dari segi likuiditas, solvabilitas, rentabilitas. Capital juga harus dilihat dari sumber mana saja modal yang ada sekarang ini.

d. Collateral

Collateral merupakan jaminan yang diberikan calon debitur baik yang bersifat fisik maupun non fisik. Jaminan juga harus diteliti keabsahannya, sehingga jika terjadi suatu masalah, maka jaminan yang "dititipkan" akan dapat dipergunakan secepat mungkin.

e. Condition of Economic

Kondisi ekonomi adalah keadaan ekonomi pada umumnya dan sifat sektor usaha calon debitur yang dapat mempengaruhi keberhasilan atau kegagalan usahanya. Demikian pula perkembangan teknologi dan perubahan kebijaksanaan pemerintah khususnya mengenai ekonomi moneter yang mungkin dapat mempengaruhi kelangsungan hidup perusahaan calon debitur.

\section{Hubungan Teknik Analisis Laporan Keuangan Dengan Pertimbangan Pemberian Kredit}

Dalam menyetujui permintaan kredit dan para debitur, kreditur harus mempertimbangkan resiko kemacetan kredit yang mungkin terjadi. Untuk memperkecil resiko tersebut, kreditur yang dalam hal ini adalah bank harus melakukan analisis terhadap laporan keuangan calon debitur. Analisis laporan keuangan bertujuan untuk mengadakan penilaian atas keadaan keuangan dan potensi atau kemajuan suatu perusahaan dengan mempelajari angka-angka yang terdapat dalam laporan keuangan perusahaan pemohon kredit. Untuk mengevaluasi permohonan kredit teknik analisa yang digunakan disesuaikan dengan kebutuhan informasi yang diperlukan atau tergantung pada pihak mana yang berkepentingan terhadap eksistensi suatu perusahaan. Kreditur sebelum mengambil keputusan untuk memberi atau menolak 
permintaan kredit dari suatu perusaahan, perlulah mengadakan analisis terlebih dulu terhadap laporan keuangan dari perusaahan yang mengajukan kredit, untuk dapat mengukur kemampuan perusahaan tersebut untuk membayar kembali hutangnya plus beban-beban bunganya.

\section{METODE}

Penelitian ini adalah penelitian kuantitatif di bidang manajemen keuangan yaitu penelitian yang menganalisa laporan keuangan debitur yang berstatus badan hukum (perusahaan) yang digunakan dalam proses pemberian kredit pada lembaga keuangan di kota Malang. Teknik analisis data yang digunakan dalam penelitian ini menggunakan analisis rasio, analisis perbandingan laporan keuangan, analisis common size.

Adapun data yang digunakan dalam penelitian ini adalah berupa salah satu data laporan keuangan debitur yang dapat dipertimbangkan atau kurang dapat dipertimbangkan yang ada pada lembaga keuangan di Kota Malang. Pada data laporan keungan ini penulis tidak mencantumkan nama debitur yang sebenarnya dengan alasan pihak lembaga keuangan tidak ingin terganggu dengan pihak debitur yang bersangkutan sesuai dengan kode etika Bank (Rahasia) dengan laporan keuangan dalam memperoleh fasilitas kredit pada lembaga keuangan di Kota Malang. HASIL

Berdasarkan hasil kajian terhadap data yang masuk dalam proses penelitian berikut disajikan beberapa data laporan keuangan yang dapat dipertimbangkan

Tabel 1

DEBITUR "A"

NERACA

Periode 2009, 20102011

(Rp. 000)

\begin{tabular}{|l|l|l|l|}
\hline & $\begin{array}{l}\mathbf{3 1}-\mathbf{1 2} \\
\mathbf{2 0 0 9}\end{array}$ & $\begin{array}{l}\mathbf{3 1}-\mathbf{1 2} \\
\mathbf{2 0 1 0}\end{array}$ & $\mathbf{3 1 - 1 2 2 0 1 1}$ \\
\hline AKTIVA & & & \\
\hline AKTIVA LANCAR & 7.125 & 7.906 & 11.769 \\
Kas \& Bank & 12.500 & 17.500 & 32.500 \\
Piutang & 175.000 & 225.000 & 318.000 \\
Persediaan & 0 & 0 & 0 \\
Uang muka & 0 & 0 & 0 \\
Aktiva lancar lainnya & 194.625 & 250.406 & 362.269 \\
JUMLAH AKTIVA LANCAR & & & \\
AKTIVA TETAP & 120.000 & 120.000 & 120.000 \\
Tanah & 122.500 & 122.500 & 122.500 \\
Bangunan & 0 & 0 & 0 \\
Mesin & 66.000 & 66.000 & 66.000 \\
Kendaraan & & &
\end{tabular}




\begin{tabular}{|l|l|l|l|} 
Inventaris & 12.000 & 12.000 & 12.000 \\
Aktiva tetap lainnya & 6.000 & 6.000 & 12.000 \\
(akumulasi penyusutan aktiva tetap) & $(14.625)$ & $(19.625)$ & $(24.625)$ \\
JUMLAH AKTIVA TETAP & 311.875 & 306.875 & 307.875 \\
\hline TOTAL AKTIVA & 506.500 & 557.281 & 670.144 \\
\hline PASSIVA & & & \\
\hline HUTANG & 17.000 & 20.000 & 23.500 \\
Hutang dagang & 0 & 0 & 0 \\
Hutang jk panjang jth tempo & 0 & 0 & 0 \\
Hutang Bank X & 0 & 0 & 0 \\
Hutang Bank lain & 17.000 & 20.000 & 23.500 \\
JUMLAH HUTANG LANCAR & 0 & 0 & 0 \\
Hutang jk pj Bank X & 0 & 0 & 0 \\
Hutang jk pj Bank lain & 0 & 0 & 0 \\
JUMLAH HUTANG JK. PANJANG & 17.000 & 20.000 & 23.500 \\
JUMLAH HUTANG & & & \\
MODAL & 0 & $(50.000)$ & $(50.000)$ \\
Prive & 405.000 & 405.000 & 405.000 \\
Modal disetor & 0 & 84.500 & 182.281 \\
Laba ditahan & 84.500 & 97.781 & 109.363 \\
Laba tahun berjalan & 489.500 & 537.281 & 646.644 \\
\hline JUMLAH MODAL & 506.500 & 557.281 & 670.144 \\
\hline TOTAL PASSIVA & &
\end{tabular}

Sumber data : Lembaga Keuangan

\section{Tabel 2 \\ DEBITUR "A" \\ LABA RUGI}

Periode 2009, 2010, 2011

(Rp. 000)

\begin{tabular}{|c|c|c|c|}
\hline & $31-12-2009$ & $31-12-2010$ & $31-12-2011$ \\
\hline \multirow{8}{*}{$\begin{array}{l}\text { Penjualan bersih } \\
\text { Harga pokok penjualan } \\
\text { LABA KOTOR } \\
\text { Biaya adm, penj dan umum } \\
\text { LABA USAHA } \\
\text { Biaya bunga } \\
\text { Biaya penyusutan } \\
\text { Biaya lainnya } \\
\text { PENDAPATAN }\end{array}$} & 995.000 & 1.125 .000 & 1.250 .000 \\
\hline & 796.000 & 900.000 & 1.000 .000 \\
\hline & 199.000 & 225.000 & 250.000 \\
\hline & 75.000 & 84.375 & 93.750 \\
\hline & 124.000 & 140.625 & 156.250 \\
\hline & 0 & 0 & 0 \\
\hline & 5.000 & 5.000 & 5.000 \\
\hline & 24.000 & 25.000 & 27.000 \\
\hline $\begin{array}{l}\text { BIAYA BUNGA } \\
\text { PENYUSUTAN }\end{array}$ & 95.000 & 110.625 & 124.250 \\
\hline Penghasilan lainnya & 0 & 0 & 0 \\
\hline $\begin{array}{l}\text { LABA } \\
\text { (EBT) }\end{array}$ & 95.000 & 110.625 & 124.250 \\
\hline $\begin{array}{l}\text { PAJÁK } \\
\text { LABA SETELAH PAJAK }\end{array}$ & $\begin{array}{l}10.500 \\
84.500\end{array}$ & $\begin{array}{l}12.844 \\
97.781\end{array}$ & $\begin{array}{l}14.888 \\
109.363\end{array}$ \\
\hline
\end{tabular}

Sumber Data : 
Sedangkan hasil penelitian dari laporan keuangan yang kurang dapat dipertimbangkan adalah sebagai berikut :

Tabel 3

DEBITUR "B"

LABA RUGI

Periode 31 Desember 2009, 2010, 2011

(Rp. 000)

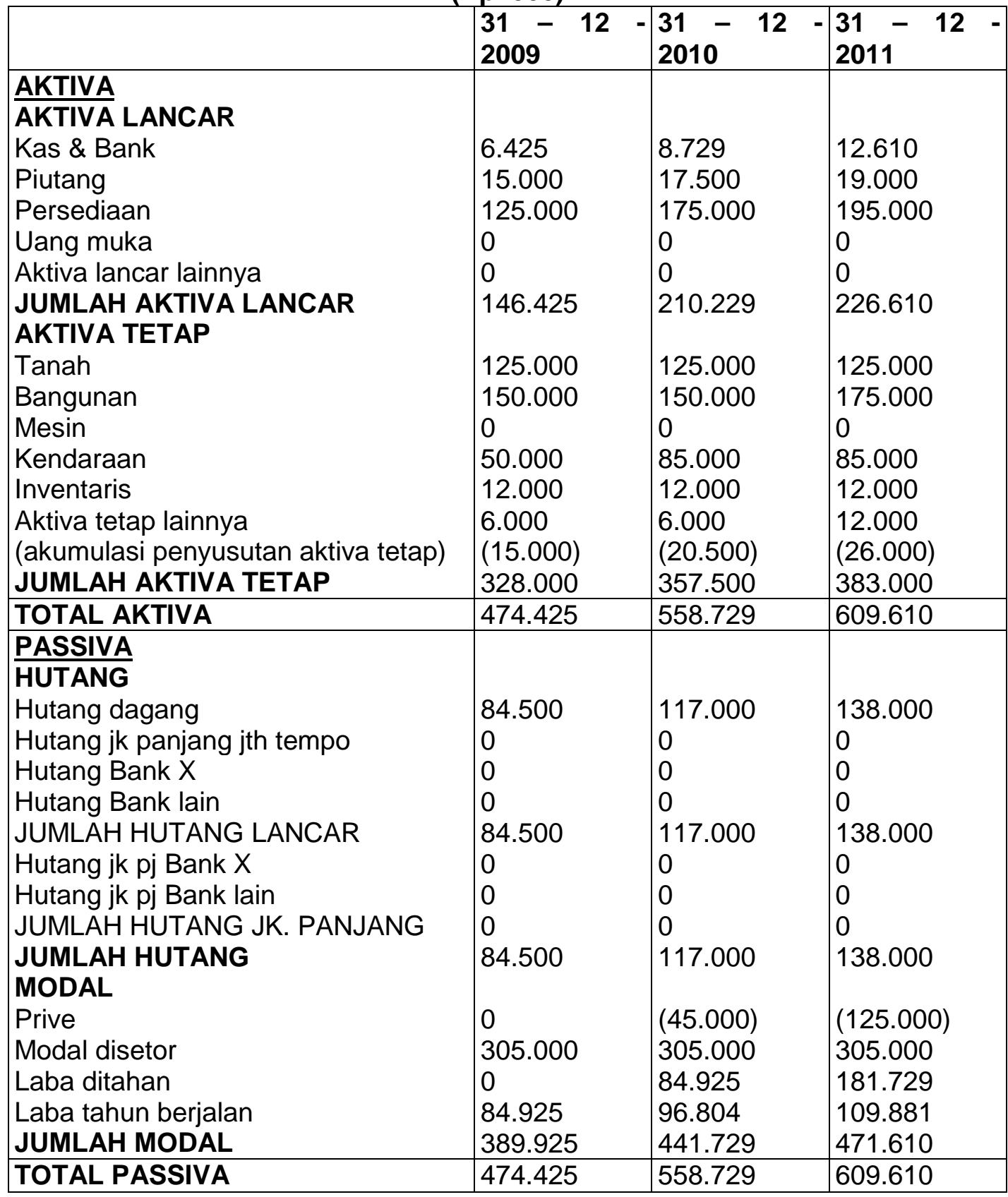

Sumber Data :

Tabel 4

DEBITUR "B"

LABA RUGI

Periode 2009, 2010, 2011

(Rp. 000) 


\begin{tabular}{|l|l|l|l|}
\hline & $\mathbf{3 1 - 1 2 - 2 0 0 5}$ & $\mathbf{3 1 - 1 2 - 2 0 0 6}$ & $\mathbf{3 1 - 1 2 - 2 0 0 7}$ \\
\hline Penjualan bersih & 850.000 & 975.000 & 1.120 .000 \\
Harga pokok penjualan & 680.000 & 780.000 & 896.000 \\
LABA KOTOR & 170.000 & 195.000 & 224.000 \\
Biaya adm, penj dan umum & 50.000 & 57.525 & 66.640 \\
LABA USAHA & 120.000 & 137.475 & 157.360 \\
Biaya bunga & 0 & 0 & 0 \\
Biaya penyusutan & 4.500 & 5.500 & 5.500 \\
Biaya lainnya & 20.000 & 22.500 & 27.000 \\
PENDAPATAN SETELAH BIAYA & & & \\
BUNGA DAN PENYUSUTAN & 95.500 & 109.475 & 124.860 \\
Penghasilan lainnya & 0 & 0 & 0 \\
LABA SEBELUM PAJAK (EBT) & 95.500 & 109.475 & 124.860 \\
PAJAK & 10.575 & 12.671 & 14.979 \\
LABA SETELAH PAJAK & 84.925 & 96.804 & 109.881 \\
\hline
\end{tabular}

Sumber Data :

\section{PEMBAHASAN}

Langkah-langkah pemecahan masalah menggunakan analisis rasio, analisis perbandingan laporan keuangan dan analisis common size. Dari hasil disajikan analisis rasio berikut, ringkasan hasil analisis rasio debitur $A$ :

Tabel 6

Ringkasan Hasil Analisis Rasio

Debitur "A"

\begin{tabular}{|c|c|c|c|c|}
\hline Analisis rasio & $\begin{array}{l}31-12- \\
2009\end{array}$ & $\begin{array}{l}31-12- \\
2010\end{array}$ & $\begin{array}{l}31-12- \\
2011\end{array}$ & keterangan \\
\hline $\begin{array}{l}\text { Rasio likuiditas } \\
\text { a. Current Ratio } \\
\text { b. Quick Ratio } \\
\text { c. }\end{array}$ & $\begin{array}{l}1.144,85 \% \\
115,44 \% \\
41,91 \%\end{array}$ & $\begin{array}{l}1.250 \% \\
127,03 \% \\
39,53 \%\end{array}$ & $\begin{array}{l}1.541,57 \% \\
188,37 \% \\
50,08 \%\end{array}$ & $\begin{array}{lr}\text { Likuiditas } & \text { untuk } \\
\text { debitur } \\
\text { dinyatakan BAIK } \\
\text { karena mengalami } \\
\text { peningkatan serta } \\
\text { memenuhi standar } \\
\text { yang ditetapkan. }\end{array}$ \\
\hline $\begin{array}{l}\text { Rasio Solvabilitas } \\
\text { a. Total Debt to Equity } \\
\text { Ratio } \\
\text { b. Total Debt to Total } \\
\text { Assets Ratio } \\
\text { c. Time Interest Earned } \\
\text { Ratio } \\
\text { d. Long Term Debt to } \\
\text { Equity Ratio }\end{array}$ & $\begin{array}{l}3,47 \% \\
3,35 \% \\
0 \\
\sim\end{array}$ & $\begin{array}{l}3,72 \% \\
3,58 \% \\
0 \\
\sim\end{array}$ & $\begin{array}{l}3,63 \% \\
3,50 \% \\
0 \\
\sim\end{array}$ & $\begin{array}{lr}\text { Solvabilitas } & \text { untuk } \\
\text { debitur } & \text { A } \\
\text { dinyatakan } & \text { BAIK } \\
\text { karena terjadinya } \\
\text { penurunan dana } \\
\text { yang berasal dari } \\
\text { hutang, dan } \\
\text { dinyatakan bahwa } \\
\text { debitur banyak } \\
\text { dibiayai oleh modal } \\
\text { sendiri } \\
\text { dibandingkan } \\
\text { hutang }\end{array}$ \\
\hline
\end{tabular}




\begin{tabular}{|c|c|c|c|c|}
\hline $\begin{array}{l}\text { Rasio Aktivitas } \\
\text { a. Total Assets Turn Over } \\
\text { b. Receivable Turn Over } \\
\text { c. Average Collection } \\
\text { Periode } \\
\text { d. Inventory Turn Over } \\
\text { e. Average Day's } \\
\text { Inventory } \\
\text { f. Working Capital Turn } \\
\text { Over }\end{array}$ & $\begin{array}{l}1,96 X \\
79,6 \text { X } \\
4,5 \text { Hari }\end{array}$ & $\begin{array}{l}2,01 X \\
64,3 X \\
5,6 \text { Hari }\end{array}$ & $\begin{array}{l}1,86 X \\
38,46 \times \\
9,4 \text { Hari }\end{array}$ & $\begin{array}{l}\text { Aktivitas untuk } \\
\text { debitur } \\
\text { dinyatakan } \\
\text { ada } \\
\text { kecenderungan } \\
\text { peningkatan } \\
\text { walaupun total } \\
\text { asset trun over nya } \\
\text { mengalami } \\
\text { penurunan. Hal ini } \\
\text { dibuktikan } \\
\text { terdapatnya } \\
\text { peningkatan } \\
\text { penggunaan aktiva } \\
\text { lancar }\end{array}$ \\
\hline $\begin{array}{l}\text { Rasio Rentabilitas } \\
\text { a. Gross Profit Margin } \\
\text { b. Operating Income } \\
\text { Ratio } \\
\text { c. Operating Ratio } \\
\text { d. Net Profit Margin } \\
\text { e. ROI } \\
\text { f. ROE }\end{array}$ & $\begin{array}{l}20 \% \\
12,46 \% \\
87,5 \% \\
8,5 \% \\
16,7 \% \\
17,3 \%\end{array}$ & $\begin{array}{l}20 \% \\
12,5 \% \\
87,5 \% \\
8,69 \% \\
17,5 \% \\
16,9 \%\end{array}$ & $\begin{array}{l}20 \% \\
12,5 \% \\
87,5 \% \\
8,75 \% \\
16,3 \% \\
18,2 \%\end{array}$ & $\begin{array}{l}\text { Rentabilitas untuk } \\
\text { debitur A } \\
\text { dinyatakan BAIK } \\
\text { dikarenakan debitur } \\
\text { mampu } \\
\text { mempertahankan } \\
\text { persen keuntungan } \\
\text { dan tingkat } \\
\text { pengembaliandari } \\
\text { bisnis atas seluruh } \\
\text { investasi }\end{array}$ \\
\hline
\end{tabular}

Berikut ringkasan hasil analisis rasio debitur B :

Tabel 8

Ringkasan Hasil Analisis Rasio

Debitur "B"

\begin{tabular}{|c|c|c|c|c|}
\hline & $\begin{array}{l}31-12 \\
2009\end{array}$ & \begin{tabular}{|l|}
$31-12-$ \\
2010
\end{tabular} & $\begin{array}{l}31-12- \\
2011\end{array}$ & keterangan \\
\hline $\begin{array}{l}\text { Rasio likuiditas } \\
\text { a. Current Ratio } \\
\text { b. Quick Ratio } \\
\text { c. Cash Ratio }\end{array}$ & $\begin{array}{l}173,28 \% \\
25,35 \% \\
7,60 \%\end{array}$ & $\begin{array}{l}179,68 \% \\
30,17 \% \\
7,46 \%\end{array}$ & $\begin{array}{l}164,21 \% \\
22,90 \% \\
9,13 \%\end{array}$ & $\begin{array}{lr}\text { Likuiditas } & \text { untuk } \\
\text { debitur } & B \\
\text { dinyatakan } & \text { TIDAK } \\
\text { BAIK } & \text { karena } \\
\text { mengalami } & \\
\text { penurunan dalam 3 } \\
\text { tahun terakhir. }\end{array}$ \\
\hline $\begin{array}{l}\text { Rasio Solvabilitas } \\
\text { a. Total Debt to Equity } \\
\text { Ratio } \\
\text { b. Total Debt to Total } \\
\text { Assets Ratio } \\
\text { c. Time Interest Earned } \\
\text { Ratio } \\
\text { d. Long Term Debt to }\end{array}$ & $\begin{array}{l}21,67 \% \\
17,81 \% \\
0 \\
\sim\end{array}$ & $\begin{array}{l}26,48 \% \\
20,58 \% \\
0 \\
\sim\end{array}$ & $\begin{array}{l}29,26 \% \\
22,63 \% \\
0 \\
\sim\end{array}$ & $\begin{array}{lr}\text { Solvabilitas } & \text { untuk } \\
\text { debitur } & \text { B } \\
\text { dinyatakan } & \\
\text { KURANG BAIK } \\
\text { karena terjadinya } \\
\text { kenaikan } \\
\text { penggunaan dana } \\
\text { yang berasal dari }\end{array}$ \\
\hline
\end{tabular}




\begin{tabular}{|c|c|c|c|c|}
\hline Equity Ratio & & & & hutang. \\
\hline $\begin{array}{l}\text { Rasio Aktivitas } \\
\text { a. Total Assets Turn } \\
\text { Over } \\
\text { b. Receivable Turn Over } \\
\text { c. Average Collection } \\
\text { Periode } \\
\text { d. Inventory Turn Over } \\
\text { e. Average } \quad \text { Day's } \\
\text { Inventory } \\
\text { f. Working Capital Turn } \\
\text { Over }\end{array}$ & $\begin{array}{l}1,79 X \\
56,67 X \\
6,4 \text { Hari } \\
\\
5,44 X \\
66,2 \text { Hari } \\
13,7 \times\end{array}$ & $\begin{array}{l}1,75 X \\
55,71 X \\
6,5 \text { Hari } \\
\\
4,46 X \\
80,7 \text { Hari } \\
10,4 X\end{array}$ & $\begin{array}{l}1,85 X \\
58,95 X \\
6,1 \text { Hari } \\
\\
4,59 X \\
78,4 \text { Hari } \\
12,6 X\end{array}$ & $\begin{array}{l}\text { Aktivitas untuk } \\
\text { debitur } \\
\text { dinyatakan } \\
\text { KURANG BAIK } \\
\text { walaupun ada } \\
\text { kecenderungan } \\
\text { peningkatan, hal ini } \\
\text { dinyatakan bahwa } \\
\text { debitur } \\
\text { dipertimbangkan } \\
\text { karenaterjadinya } \\
\text { penurunan } \\
\text { terhadap aktivitas } \\
\text { dalam penagihan. }\end{array}$ \\
\hline $\begin{array}{l}\text { Rasio Rentabilitas } \\
\text { a. Gross Profit Margin } \\
\text { b. Operating Income } \\
\quad \text { Ratio } \\
\text { c. Operating Ratio } \\
\text { d. Net Profit Margin } \\
\text { e. ROI } \\
\text { f. ROE }\end{array}$ & $\begin{array}{l}20 \% \\
14,12 \% \\
85,88 \% \\
9,99 \% \\
17,98 \% \\
21,78 \%\end{array}$ & $\begin{array}{l}20 \% \\
14,1 \% \\
85,9 \% \\
9,93 \% \\
17,39 \% \\
21,91 \%\end{array}$ & $\begin{array}{l}20 \% \\
14,05 \% \\
85,95 \% \\
9,81 \% \\
18,11 \% \\
23,3 \%\end{array}$ & $\begin{array}{lr}\text { Rentabilitas untuk } \\
\text { debitur A } \\
\text { dinyatakan BAIK } \\
\text { walaupun } \\
\text { dikarenakan debitur } \\
\text { tidak mampu } \\
\text { mempertahankan } \\
\text { persen keuntungan } \\
\text { tetapi adanya } \\
\text { peningkatan }\end{array}$ \\
\hline
\end{tabular}

ANALISIS COMMON SIZE

Tabel 13

DEBITUR " $A$ "

Hasil Analisis Common Size

NERACA

Per 31 Desember 2009, 2010, 2011

(Rp. 000)

\begin{tabular}{|c|c|c|c|c|c|c|}
\hline \multirow{2}{*}{ KETERANGAN } & \multicolumn{2}{|c|}{$31-12-2009$} & \multicolumn{2}{|c|}{$31-12-2010$} & \multicolumn{2}{|c|}{$31-12-2011$} \\
\hline & $R p$ & $\%$ & Rp & $\%$ & $\mathbf{R p}$ & $\%$ \\
\hline$\frac{\text { AKTIVA }}{\text { AKTIVA LANCAR }}$ & & & & & & \\
\hline Kas \& Bank & 7.125 & 1,01 & 7.906 & 1,06 & 12.763 & 1,46 \\
\hline Piutang & 12.500 & 2,48 & 17.500 & 3,15 & 3.500 & 4,86 \\
\hline Persediaan & 175.000 & 34,69 & 225.000 & 40,52 & 318.000 & 47,59 \\
\hline Uang muka & 0 & & 0 & 0 & 0 & 0 \\
\hline Aktiva lancar lainnya & & & & & & \\
\hline $\begin{array}{ll}\text { JUMLAH } & \text { AKTIVA } \\
\text { LANCAR } & \\
\text { AKTIVA TETAP } & \end{array}$ & 194.625 & 38,18 & 250.406 & 44,74 & 362.269 & 53,92 \\
\hline Tanah & 120.000 & 23,79 & 120.000 & 21,61 & 120.000 & 17,96 \\
\hline
\end{tabular}




\begin{tabular}{|c|c|c|c|c|c|c|}
\hline Bangunan & 122.500 & 24,28 & 122.500 & 22,06 & 122.500 & 18,33 \\
\hline Mesin & & & & & & \\
\hline Kendaraan & 66.000 & 13,08 & 66.000 & 11,89 & 66.000 & 9,88 \\
\hline Inventaris & 12.000 & 2,38 & 12.000 & 2,16 & 12.000 & 1,80 \\
\hline Aktiva tetap lainnya & 6.000 & 1,19 & 6.000 & 1,08 & 12.000 & 1,80 \\
\hline $\begin{array}{l}\text { (akumulasi } \\
\text { aktiva tetap) }\end{array}$ & $(14.625)$ & $(2,90)$ & (19.625) & $(3,53)$ & $(24.625)$ & $(3,69)$ \\
\hline JUMLAH AKTIVA TETAP & $311 . \varepsilon$ & 61,82 & 306. & 55,26 & 307.875 & 46,08 \\
\hline TOTAL AKTIVA & & 100 & & 100 & 44 & 100 \\
\hline $\begin{array}{l}\text { PASSIVA } \\
\text { HUTANG }\end{array}$ & & & & & & \\
\hline lagang & 17.000 & 3,35 & 20.000 & 3,35 & 23.500 & 3,50 \\
\hline jjang jth tempo & & & & & 0 & \\
\hline Bank X & 0 & 0 & 0 & 0 & 0 & 0 \\
\hline g Bank lain & 0 & & & & & \\
\hline $\begin{array}{ll}\text { JUMLAHH } & \text { HUTANG } \\
\text { LANCAR } & \end{array}$ & 17.000 & 3,35 & 20.000 & 3,35 & 23.500 & 3,50 \\
\hline ng jk pj Bank X & 0 & 0 & 0 & 0 & 0 & 0 \\
\hline Hutang jk pj Bank lain & 0 & 0 & 0 & 0 & 0 & 0 \\
\hline $\begin{array}{lll}\text { JUMLAH } & \text { HUTANG } & \text { JK. } \\
\text { PANJANG } & & \end{array}$ & 0 & 0 & 0 & 0 & 0 & 0 \\
\hline $\begin{array}{l}\text { JUMLAH HUTANG } \\
\text { MODAL }\end{array}$ & 17.000 & 3,35 & 20.000 & 3,35 & 23.500 & 3,50 \\
\hline Prive & 0 & 0 & $(50.000)$ & $(9,00)$ & (50.000) & $(7,48)$ \\
\hline Modal disetor & 405.000 & 80,28 & 405.0 & 72,94 & 405.000 & 60,62 \\
\hline Laba ditahan & & 0 & 84.500 & 15,22 & 182.281 & 27,28 \\
\hline un berjalan & 84.500 & 16,75 & 97.781 & 17,61 & 109.363 & 16,37 \\
\hline JUMLAH MODAL & 489.500 & 97,03 & 537.281 & 96,76 & 646.644 & 96,78 \\
\hline TOTAL PASSIVA & 506.500 & 100 & 557.281 & 100 & 670.144 & 100 \\
\hline
\end{tabular}

Tabel 14

DEBITUR "A"

Hasil Analisis Common Size

LABA RUGI

Per 31 Desember 2009, 2010, 2011

(Rp. 000)

\begin{tabular}{|c|c|c|c|c|c|c|}
\hline & \multicolumn{2}{|c|}{$31-12-2009$} & \multicolumn{2}{|c|}{$31-12-2010$} & \multicolumn{2}{|c|}{$31-12-2011$} \\
\hline & $\mathbf{R p}$ & $\%$ & $\mathrm{Rp}$ & $\%$ & $\mathrm{Rp}$ & $\%$ \\
\hline Penjualan bersih & 995.000 & 100 & 1.125 .000 & 100 & 1.250 .000 & 100 \\
\hline Harga pokok penjualan & 796.000 & 80 & 900.000 & 80 & 1.000 .000 & 80 \\
\hline LABA KOTOR & 199.000 & 20 & 225.000 & 20 & 250.000 & 20 \\
\hline Biaya adm, penj dan umum & 75.000 & 7,54 & 84.375 & 7,50 & 93.750 & 7,50 \\
\hline LABA USAHA & 124.000 & 12,46 & 140.625 & 12,50 & 156.250 & 12,50 \\
\hline Biaya bunga & & & & & & \\
\hline Biaya penyusutan & 5.000 & 0,50 & 5.000 & 0,44 & 5.000 & 0,40 \\
\hline $\begin{array}{l}\text { Biaya lainnya } \\
\text { PENDAPATAN SETELAH }\end{array}$ & 24.000 & 2,41 & 25.000 & 2,22 & 27.000 & 2,16 \\
\hline BIAYA BUNGA DAN & & & & & & \\
\hline $\begin{array}{l}\text { PENYUSUTAN } \\
\text { Penghasilan lainnya }\end{array}$ & 95.000 & $\begin{array}{l}9,55 \\
0\end{array}$ & 110.625 & 9,83 & 124.250 & $\begin{array}{l}9,94 \\
0\end{array}$ \\
\hline $\begin{array}{l}\text { LABA SEBELUM PAJAK } \\
\text { (EBT) }\end{array}$ & 95.000 & 9,55 & 110.625 & 9,83 & 124.250 & 9,94 \\
\hline
\end{tabular}




\begin{tabular}{|l|l|l|l|l|l|l|} 
PAJAK & 10.500 & 1,06 & 12.844 & 1,14 & 14.888 & 1,19 \\
LABA SETELAH PAJAK & 84.500 & 8,49 & 97.781 & 8,69 & 109.363 & 8,75 \\
\hline
\end{tabular}

Dari analisis common size yang telah dilakukan, dapat diketahui bahwa pada tahun 2011 4,86\% aktiva adalah dalam bentuk piutang dagang, dan 47,59\% tertanam dalam bentuk persediaan barang. Dalam golongan yang lebih besar kita melihat bahwa 53,92\% aktiva adalah dalam bentuk aktiva lancar. Pada tahun 2011 3,22\% aktiva debitur "A" dibiayai dana pihak luar (utang) dan semuanya hanya berasal dari hutang dagang. Dan 96,78 \% aktiva dibiayai oleh modal sendiri. Dan keadaan tersebut diperkuat dengan kenaikan kontribusi modal sendiri dari 96,76 \% pada tahun 2010 menjadi 96,78\% pada tahun 2011.

Sumbangan dari masing-masing pos biaya terhadap penjualan dapat dikenali dengan cepat dengan memperhatikan prosentase masing-masing pos tersebut terhadap penjualan. Untuk debitur "A" $80 \%$ adalah harga pokok penjualan, 7,5\% biaya operasional, $0,40 \%$ biaya penyusutan dan $2,16 \%$ merupakan biaya lainnya. Keberhasilan yang dapat dicapai oleh debitur "A" terletak pada kemampuannya untuk menekan ketiga komponen biaya dari tahun 2009 sampai tahun 2010 yang mengalami penurunan dan mampu mempertahankan harga pokok penjualannya.

Tabel 15

DEBITUR "B"

Hasil Analisis Common Size

NERACA

Per 31 Desember 2009, 2010, 2011

(Rp. 000)

\begin{tabular}{|c|c|c|c|c|c|c|}
\hline \multirow{2}{*}{ KETERANGAN } & \multicolumn{2}{|c|}{$31-12-2009$} & \multicolumn{2}{|c|}{$31-12-2010$} & \multicolumn{2}{|c|}{$31-12-2011$} \\
\hline & $\mathbf{R p}$ & $\%$ & $\mathbf{R p}$ & $\%$ & $\mathrm{Rp}$ & $\%$ \\
\hline$\frac{\text { AKTIVA }}{\text { AKTIVA LANCAR }}$ & & & & & & \\
\hline & 425 & 0,94 & 8.729 & 1,21 & 12.610 & 1,58 \\
\hline & 5.000 & 3,18 & & 3,14 & 00 & 3,13 \\
\hline aan & 125. & 26,46 & 175. & 31,43 & 00 & 32,15 \\
\hline Uar & 0 & 0 & 0 & 0 & 0 & 0 \\
\hline r lainnva & 0 & 0 & 0 & 0 & 0 & 0 \\
\hline $\begin{array}{l}\text { KTIVA LANCAR } \\
\text { TAP }\end{array}$ & 146.425 & 30,57 & 210.229 & 35,79 & 226.610 & 36,86 \\
\hline Tana & 125.000 & 26,46 & 125.000 & 22,45 & 125.000 & 20,6 \\
\hline Bar & 150.000 & 31,75 & 150.000 & 26,94 & 175.000 & 28,85 \\
\hline Mesi & & & & & & \\
\hline Kendaraan & 50.000 & 10,58 & 85.000 & 15,27 & 85.000 & 14,01 \\
\hline Inventaris & 12.0 & 2,54 & 12.0 & 2,16 & 12.000 & 1,98 \\
\hline Aktiva tetap la & 6.000 & 1,27 & 6.000 & 1,08 & 12.000 & 1,98 \\
\hline $\begin{array}{ll}\text { (akumulasi } & \text { penyusutan } \\
\text { aktiva tetap) } & \end{array}$ & $(15.000)$ & $(3,18)$ & (20.500) & $(3,68)$ & $(26.000)$ & $(4,29)$ \\
\hline
\end{tabular}




\begin{tabular}{|c|c|c|c|c|c|c|}
\hline JUMLAH AKTIVA TETAP & 328.000 & 69,43 & 357.500 & 64,21 & 383.000 & 63,14 \\
\hline TOTAL AKTIVA & 474.425 & 100 & 558.729 & 100 & 609.610 & 100 \\
\hline$\frac{\text { PASSIVA }}{\text { HUTANG }}$ & & & & & & \\
\hline Hutang dagang & 84.500 & 17,46 & 117.000 & 20,66 & 138.000 & 22,25 \\
\hline Hutang jk panjang jth tempo & 0 & 0 & 0 & & & 0 \\
\hline Hutang Bank X & 0 & 0 & 0 & 0 & 0 & 0 \\
\hline Hutang Bank lain & 0 & 0 & & & & 0 \\
\hline JUMLÄH HUTANG LANCAR & 84.500 & 17,46 & 117.000 & 20,66 & 138.000 & 22,25 \\
\hline Hutang jk pj Bank X & 0 & 0 & 0 & 0 & 0 & 0 \\
\hline Hutang jk pj Bank lain & 0 & 0 & 0 & 0 & 0 & 0 \\
\hline $\begin{array}{l}\text { PANJANG } \\
\text { JUMLAH HUTANG } \\
\text { MODAL }\end{array}$ & $\begin{array}{l}0 \\
84.500\end{array}$ & $\begin{array}{l}0 \\
17,46\end{array}$ & $\begin{array}{l}0 \\
117.000\end{array}$ & $\begin{array}{l}0 \\
20,66\end{array}$ & $\begin{array}{l}0 \\
138.000\end{array}$ & $\begin{array}{l}0 \\
22,25\end{array}$ \\
\hline Prive & 0 & 0 & $(45.000)$ & $(8,08)$ & $(125.000)$ & $(20,61)$ \\
\hline Modal disetor & 305.000 & 64,56 & 305.000 & 54,78 & 305.000 & 50,28 \\
\hline Laba ditahan & 0 & 0 & 84.925 & 15,25 & 181.729 & 29,96 \\
\hline Laba tahun berjalan & 84.925 & 17,98 & 96.804 & 17,39 & 109.881 & 18,11 \\
\hline JUMLAH MODAL & 389.925 & 82,54 & 441.729 & 79,34 & 471.610 & 77,75 \\
\hline TOTAL PASSIVA & 474.425 & 100 & 558.729 & 100 & 609.610 & 100 \\
\hline
\end{tabular}

Tabel 16

DEBITUR "B

Hasil Analisis Common Size

LABA RUGI

Per 31 Desember 2009, 2010, 2011

(Rp. 000)

\begin{tabular}{|c|c|c|c|c|c|c|}
\hline & \multicolumn{2}{|c|}{$31-12-2009$} & \multicolumn{2}{|c|}{$31-12-2010$} & \multicolumn{2}{|c|}{$31-12-2011$} \\
\hline & $\mathrm{Rp}$ & $\%$ & $\mathrm{Rp}$ & $\%$ & $\mathrm{Rp}$ & $\%$ \\
\hline Penjualan bersih & 850.0 & & 75.000 & 100 & 1.120 .000 & 100 \\
\hline jjualan & & 80 & & 80 & 96.000 & 80 \\
\hline & & 20 & & 20 & 00 & 20 \\
\hline nj dan umum & 50.0 & 5,88 & 25 & 5,9 & 6.640 & 5,95 \\
\hline LAB & 120 & & & 14,1 & & \\
\hline Biay & & & & & 0 & 0 \\
\hline Bia) & 4.500 & 0,53 & 500 & 0,56 & 500 & 0,49 \\
\hline $\begin{array}{l}\text { Biaya lainnya } \\
\text { PENDAPATAN SETELAH }\end{array}$ & & & & & & 2,41 \\
\hline BIAYA BUNGA DAN & & & & & & \\
\hline PENYUSUTAN & 95.500 & 11,24 & 109.475 & 11,23 & 124.860 & 11,1 \\
\hline $\begin{array}{l}\text { Penghasilan lainnya } \\
\text { LABA SEBELUM PAJAK }\end{array}$ & $\begin{array}{l}0 \\
95500\end{array}$ & $\begin{array}{l}0 \\
1121\end{array}$ & $\begin{array}{l}0 \\
109475\end{array}$ & $\begin{array}{l}0 \\
1123\end{array}$ & $\begin{array}{l}0 \\
124860\end{array}$ & $\begin{array}{l}0 \\
11,1\end{array}$ \\
\hline 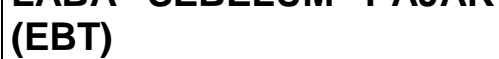 & 00.000 & & & & & \\
\hline AJAK & & 1.24 & 12.671 & & & 1,34 \\
\hline LABA SETELAH PAJAK & 84.925 & 9,99 & 96.804 & 9,93 & 109.881 & 9,81 \\
\hline
\end{tabular}


Dari hasil analisis common size untuk debitur "B" yang telah dilakukan, dapat diketahui bahwa pada tahun 2007 3,13\% aktiva adalah dalam bentuk piutang, dan $32,15 \%$ tertanam dalam bentuk persediaan barang. Dalam golongan yang lebih besar kita melihat bahwa $36,86 \%$ aktiva adalah dalam bentuk aktiva lancar. Common size dari sisi lain neraca, yaitu kewajiban dan modal, memberikan gambaran mengenai peran masing-masing pos dalam membiayai aktiva. Pada tahun 2011 22,25\% aktiva debitur "B" dibiayai melalui dana pihak luar (utang) dan semuanya hanya berasal dari hutang dagang. Dan $77,75 \%$ aktiva dibiayai oleh modal sendiri. Meskipun perusahaan lebih banyak menggunakan modal sendiri, tetapi kontribusinya mengalami penurunan dari 82,54 \% menjadi 79,34\% dan 77,75\% pada tahun 2011.

Sumbangan dari masing-masing pos biaya terhadap penjualan dapat dikenal dengan cepat, dengan memperhatikan prosentase masing-masing pos tersebut terhadap penjualan. Sumbangan harga pokok penjualan debitur "B" adalah $80 \%$ terhadap penjualan, 5,59 \% untuk biaya operasional, 0,49 \% untuk biaya penyusutan dan 2,41 \% untuk biaya !ainnya. Ketidakmampuan debitur "B" dalam menekan komponen biaya menjadikan kondisi keuangannya kurang baik. Karena mulai tahun 2009 sampai tahun 2011 biaya operasi, biaya penyusutan dan biaya lainnya mengalami kenaikkan sehingga akan menyebabkan penurunan kontribusi laba terhadap penjualan walaupun nilai rupiahnya mengalami kenaikan.

\section{SIMPULAN}

Beberapa kredit yang telah diberikan mengalami kemacetan dalam pengembaliannya, kredit macet disebabkan karena pihak lembaga keuangan kurang teliti dalam menganalisis laporan keuangan debitur sehingga salah dalam pengambilan keputusan kredit.

Kebijakan pemberian kredit yang didasarkan pada analisis laporan keuangan debitur pada lembaga keuangan di kota Malang (1) Dalam melakukan analisis laporan keuangan perusahaan calon debitur, pihak Bank hanya menggunakan tiga teknik analisis yaitu analisis rasio, analisis perbandingan laporan keuangan dan analisis common size.(2) Beberapa ketentuan yang ditetapkan oleh bank dalam menganalisis laporan keuangan calon debitur : Quick Ratio lebih besar dari 140\%, Current Ratio lebih besar dari 35\%, ROA tahun terakhir lebih besar dari ROA tahun sebelumnya, Profit Margin tahun terakhir lebih besar dari Profit Margin tahun sebelumnya. (3)Fakktor -faktor lainnya yang mendukung pengambilan keputusan kredit. 
Penilaian yang penting dalam mengetahui keadaan debitur adalah dengan melakukan pengamatan dengan prosedur untuk mengetahui kewajaran dan kebenarannya. Kewajibannya dengan tepat waktu, serta mampu memelihara modal kerja yang cukup untuk operasi yang normal serta dapat memelihara tingkat kredit dan mampu menekan tingkat biaya operasinya merupakan hal utama dalam penilaian kredit.

\section{DAFTAR PUSTAKA}

Bambang, S. 2005 Manajemen Akuntansi. Cetakan Pertama. PT. Sansumoto. Jakarta.

Baridwan, Zaki. 2000. Intermediate Accounting. Edisi Ketujuh. Cetakan Pertama Penerbit BPFE. Yogyakarta.

Cole, L.P. (1988), Management Accounting in Bank, Bank Administration Institute, Rolling Meadows, IL.

El-Hawary, D., Grais, W. and lqbal, Z. (2007), Diversity in the regulation of Islamic financial institutions, The Quarterly Review of Economics and Finance, Vol. 46 No. 5 , pp. $778-800$.

Hasibuan, Malayu, S.p. 2001. Dasar-dasar Perbankan. Penerbit PT. Bumi Aksara. Jakarta.

IAI. 2010. Pernyataan Standar Akuntansi. Penerbit Salemba Empat. Jakarta.

Jane, Tri. 2007. Analisis Laporan Keuangan sebagai kelayakan pemberian Kredit Usaha Pada Bank Rakyat Indonesia Cab Bandung

Jusuf, Jopie. 2003. Analisis Kredit Untuk Account Officer. Penerbit PT. Gramedia Pustaka Utama. Jakarta.

Kafafian, R.E. 2001. Keys to community bank success: utilizing management information to make informed decision, Journal of Bank Cost \& Management Accounting, Vol. 14 No. 1,pp. 3-4.

Kusuma, Adi. 2005. Analisis Laporan Keuangan Calon Debitur Dalam Pemberian Kredit Pada Bank Mandiri Cabang Riau.

Munawir, S. 2002. Analisis Laporan Keuangan. Edisi Keempat. Cetakan Kelima. Penerbit Liberty. Yogyakarta.

Manurung, Rahardjo, Prathama, Mandala. 2004. Uang, Perbankan dan Ekonomi Moneter (Kajian Kontekstual Indonesia). Penerbit Fakultas Ekonomi Universitas Indonesia. Jakarta.

Rezaee, Z. 2005., The relevance of managerial accounting concepts in banking industry, Journal of Performance Management, Vol. 18 No. 2, pp. 3-16. 
Sartono, Agus. 2001. Analisis Laporan Keuangan. Edisi Ketiga. Cetakan Pertama. Penerbit BPFE. Yogyakarta.

Sinkey, J.F. 2002. Commercial Bank Financial Management: In the Financial-services Industry, 6th ed, Prentice-Hall, Upper Saddle River, NJ.

Sudharma. 2000. Pengantar Analisis Kredit. Penerbit dan Percetakan. (UPP) AMP YKPN. Yogyakarta.

Suhardjono. 2003. Manajemen Perkreditan Usaha Kecil dan Menengah. Penerbit dan Percetakan. (UPP) AMP YKPN. Yogyakarta.

Syamsudin, Lukman. 2001. Manajemen Keuangan Perusahaan. Penerbit PT. Raja Grafindo Persada. Jakarta.

Undang-undang No. 10 Tahun 1998. Tentang Pokok-pokok Perbankan 